\title{
Frequencies of polymorphisms in CYP2C9 and VKORC1 genes influencing warfarin metabolism in Slovak population: implication for clinical practice
}

\author{
Krajciova $\mathrm{L}^{1,2}$, Deziova $\mathrm{L}^{2}$, Petrovic $\mathrm{R}^{2,3}$, Luha $\mathrm{J}^{3}$, Turcani $\mathrm{P}^{1}$, Chandoga $\mathrm{J}^{2,3}$ \\ 1st Department of Neurology, University Hospital Bratislava, Bratislava, Slovakia. \\ lubica1.krajciova@gmail.com
}

\begin{abstract}
Objectives: The study was aimed at establishing an effective molecular-genetic method for detecting polymorphisms in genes CYP2C9 and VKORC1, which affect the pharmacogenetics of warfarin, and at determining their prevalence in Slovak population.

Background: Warfarin, derivative of coumarin, belongs to the most commonly prescribed oral anticoagulants with narrow therapeutic index. An insufficient dose of warfarin can result in failure to produce the antithrombotic effect, whereas an overdose increases the risk of bleeding. It was proven that genetic variability in two genes, CYP2C9 a VKORC1, has a significant influence on the individual's response to the dosage of warfarin. Methods: In a control group of 112 randomly selected individuals, we tested the frequency of selected single nucleotide polymorphisms including CYP2C9*2 (430C>T), CYP2C9*3 $(1075 A>C), V K O R C 1 * 2(1173 C>T)$ by allele-specific Real-Time PCR and VKORC1*2 (-1639G>A) by using PCR-RFLP.

Results: Due to the combination of frequent alleles CYP2C9*2, CYP2C9*3 and VKORC1*2 in Slovak population we determine that $25 \%$ of population need a standard $5-\mathrm{mg}$ daily dose of warfarin, while $44 \%, 23 \%$, and $8 \%$ need $4 \mathrm{mg}, 3 \mathrm{mg}$ and $2 \mathrm{mg}$ of warfarin per day.

Conclusion: Slovak population is in Hardy-Weinberg equilibrium and frequencies of SNPs were in accordance with other published results in European populations (Tab. 5. Fig. 3, Ref. 51). Text in PDF www.elis.sk.

Key words: warfarin, pharmacogenetics, CYP2C9, VKORC1, polymorphisms.
\end{abstract}

Warfarin as well as other 4-hydroxycoumarin derivates is used as an oral anticoagulant. It functions as an antagonist of vitamin $\mathrm{K}$, which is a necessary factor of the blood clotting cascade (1). Nowadays it is one of the drugs most commonly used in prevention or therapy of some disorders. High risk of embolisms, heart attack, atrial fibrillation, some of inherited blood coagulation diseases, and conditions after surgery (e.g. heart valve) are treated with warfarin. Also, it is used as a prevention treatment in patients at high risk of stroke or in relapse of deep vein thrombosis (2). The essential anticoagulant effect of warfarin is induced by the inhibition of vitamin $\mathrm{K}$ epoxide reductase (VKOR), which leads to a decrease in vitamin K-dependent coagulation protein synthesis (3). The commercially used warfarin is a racemic mixture of S- and

${ }^{1} 1$ st Department of Neurology, University Hospital Bratislava, Bratislava, Slovakia, ${ }^{2}$ Institute of Medical Biology, Genetics and Clinical Genetics, Comenius University Faculty of Medicine, University Hospital Bratislava, Bratislava, Slovakia, and ${ }^{3}$ Institute of Medical Biology, Genetics and Clinical Genetics, Bratislava, Slovakia

Address for correspondence: L. Krajciova, Mgr, Institute of Medical Biology, Genetics and Clinical Genetics, Comenius University Faculty of Medicine, University Hospital Bratislava, Mickiewiczova 13, SK-813 69 Bratislava, Slovakia. Phone: +421.907655712

Acknowledgements: The study was supported by the Grant of Comenius University for Young Researchers, Nr. UK/279/2012 and Nr. UK/590/2013.
R-enantiomers. These isoforms have mutually different metabolic effects. S-warfarin is about five times more active than R-warfarin (4). After oral intake, warfarin is transported to the liver, where R enantiomer is metabolized by cytochromes (CYP1A1, CYP1A2 and CYP3A4) and more effective $\mathrm{S}$ enantiomer is metabolized by cytochrome P450 (CYP2C9) (5). Gamma-glutamyl carboxylase (GGCX) participates in the activation of the hypofunctional prothrombin clotting factors II, VII, IX, X to its active form (6). A reduced form of vitamin $\mathrm{K}$ influenced by VKOR takes part in the clotting process (Fig. 1). VKOR influences both warfarin enantiomers, which leads into a decrease in their efficiency (7).

The enzyme activity affecting the metabolism of warfarin can be expressed at different phenotypes levels, usually called as $\mathrm{NM}$ - normal metabolizers, IM - intermediate metabolizers, and $\mathrm{PM}$ - poor metabolizers. The time required to achieve stable concentration of warfarin in serum varies also in dependence on the genotype of each patients (8).

According to up-to-date knowledge, warfarin metabolism is mainly influenced by genetic factors such as polymorphisms affecting CYP2C9 enzyme activity and pharmacokinetics (4) and pharmacodynamics of VKORC1 (9).

CYP2C9 is located on chromosome 10 and consists of 9 exons and 8 introns. The CYP2C9 gene is highly polymorphic. Two allelic variants, CYP2C9*2 (430C $>$ T, rs 1799853) and CYP2C9*3 $(1075 \mathrm{~A}>\mathrm{C}$, rs 1057910) differing from the wild-type CYP2C9*1 


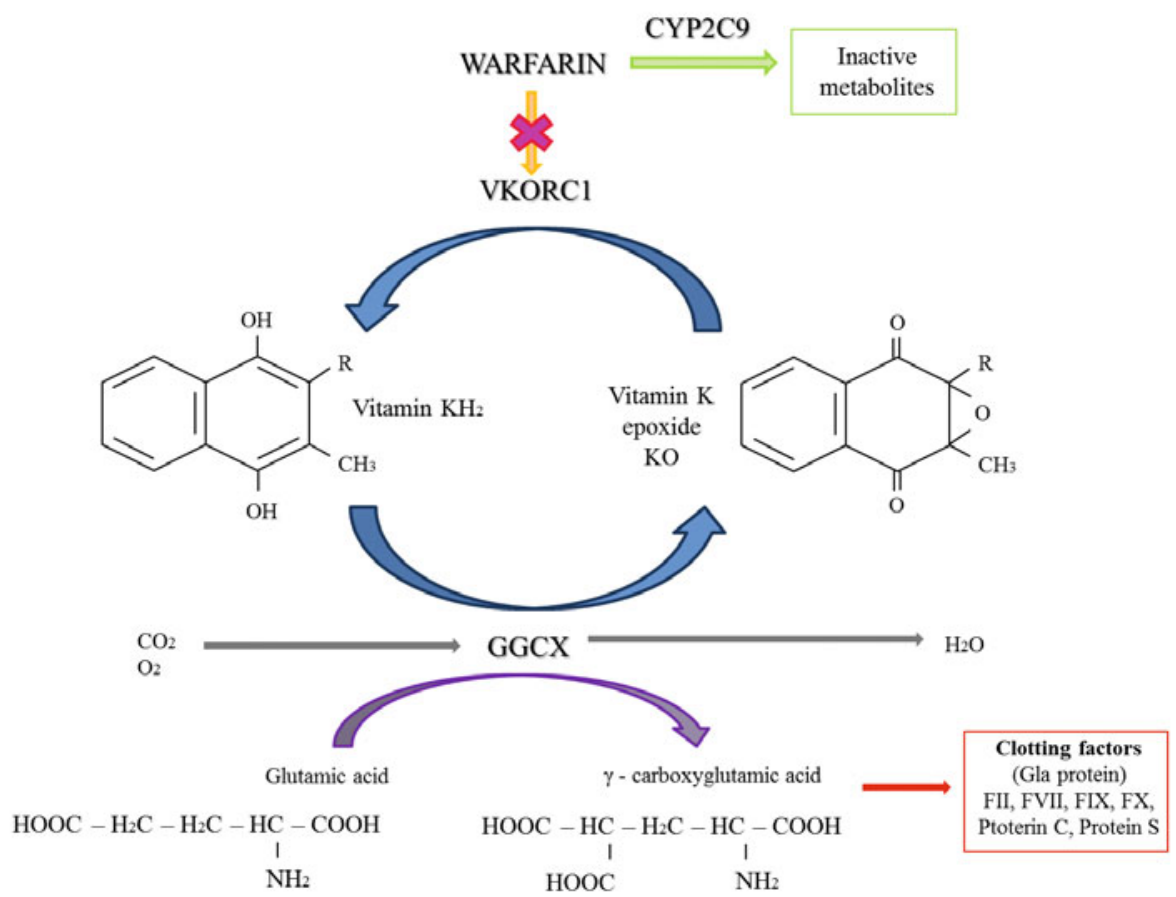

Fig. 1. Mechanism of action of warfarin and roles of CYP2C9 and VKORC1 in modulating anticoagulation. Warfarin exerts its pharmacological effect by inhibiting VKORC1. VKORC1 is the vitamin K cycle enzyme controlling regeneration of reduced vitamin $\mathrm{K}$, an essential cofactor that drives formation of the clotting factors. CYP2C9 is the major P450 enzyme that metabolizes $S$-warfarin to inactive metabolites. CYP2C9 - Cytochrome P4502C9; VKORC1 - vitamin K epoxide reductase complex 1, GGCX - gammaglutamyl carboxylase.

by a single point mutation, have been associated with reduced metabolic clearance of CYP2C9 substrates (such as warfarin and phenytoin) as compared to the wild-type. Thus a standard dose may result in raised serum drug levels (10). CYP2C9*2 is located in exon 3 and the incidence of allele $\mathrm{T}$ in Caucasians is $10-20 \%$. CYP2C $9 * 3$ is located in exon 7 and the incidence of allele $\mathrm{C}$ in Caucasians is $8 \%$ (11). Both of these allelic variants are less frequent in Asian and Afro-American people (12). Polymorphic forms of enzymes lead to a decrease in hydroxylation of S-warfarin in vitro and patients with this genotype belong to the PM phenotype. In the early stages of therapy, PM phenotypes are at risk of increased bleeding after warfarin treatment. These individuals require lower doses of warfarin to achieve the desired anticoagulant effect compared to patients with at least one CYP2C9*1 (WT) haplotype (13). The enzyme activity is reduced to $12 \%(\mathrm{CYP} 2 \mathrm{C} 9 * 2)$ and $5 \%(\mathrm{CYP} 2 \mathrm{C} 9 * 3)$, respectively to WT (14). Studies show that CYP2C9 genotype is responsible for $12 \%$ of interindividual variability in response to warfarin therapy (12).

VKORC1 is located on chromosome 16 and consists of 3 exons and 2 introns (1). Common polymorphisms in the regulatory region of VKORC1 gene correlate strongly with warfarin response across the normal dosing range (15). Polymorphisms in VKORC1 gene significantly change the pharmacodynamics and dosage adequacy of warfarin (16). The most frequent and most deeply studied polymorphisms are VKORC1 $-1639 \mathrm{G}>\mathrm{A}$ and $1173 \mathrm{C}>\mathrm{T}$. These SNPs, in the promotor and first intron of VKORC1 gene influence the enzymatic activity of VKOR (17) which is an enzyme in vitamin K cycles and the pharmacological target of coumarins (18). VKORC1 $1173 \mathrm{C}>\mathrm{T}$, rs 9934438 is in almost complete linkage disequilibrium with the polymorphism of VKORC1 -1639G $>$ A, rs9923231 where both associate with increased sensitivity to warfarin (16). These SNPs are responsible for $30 \%$ of interindividual variability in warfarin treatment (7). Haplotype VKORC1*2 is present in $42 \%$ of Europeans (19) and is relatively rare in Asian population (20).

The management of warfarin therapy is challenging because on the one hand there is a large variability in dose requirements (0.5-60 mg per day) necessary for effective therapy and on the other hand there is the risk of life-threatening bleeding (21). The range of warfarin doses for individual genotypes is based on numerous conducted studies. To determine the warfarin dose, we have to take into account age, race, weight, height, sex, other medications, as well as polymorphisms in genes CYP2C9 and VKORC1 (22). The prediction of dosing based on genotypes is presented in Table 1 (23).

\section{Material and methods}

The control group consists of 112 individuals, all healthy subjects of Caucasian origin. Participants signed an informed consent before the study. They were randomly selected and never treated with warfarin. Blood samples for DNA extraction were collected in 3-mL tubes containing potassium EDTA. DNA was extracted from $200 \mu 1$ whole blood by using DNA NucleoSpin Blood Kit (Macherey-Nagel). The frequencies of selected single 
Tab. 1. Influence of genotype effect on warfarin dose per day.

\begin{tabular}{lcccccc}
\hline \multirow{2}{*}{ VKORC1 genotype } & \multicolumn{7}{c}{ CYP2C9 genotype } \\
\cline { 2 - 7 } & $* 1 / * 1$ & $* 1 / * 2$ & $* 1 / * 3$ & $* 2 / * 2$ & $* 2 / * 3$ & $* 3 / * 3$ \\
\hline$* 1 / * 1$ & $5-7 \mathrm{mg}$ & $5-7 \mathrm{mg}$ & $3-4 \mathrm{mg}$ & $3-4 \mathrm{mg}$ & $3-4 \mathrm{mg}$ & $0.5-2 \mathrm{mg}$ \\
\hline$* 1 / * 2$ & $5-7 \mathrm{mg}$ & $3-4 \mathrm{mg}$ & $3-4 \mathrm{mg}$ & $3-4 \mathrm{mg}$ & $0.5-2 \mathrm{mg}$ & $0.5-2 \mathrm{mg}$ \\
\hline$* 2 / * 2$ & $3-4 \mathrm{mg}$ & $3-4 \mathrm{mg}$ & $0.5-2 \mathrm{mg}$ & $0.5-2 \mathrm{mg}$ & $0.5-2 \mathrm{mg}$ & $0.5-2 \mathrm{mg}$ \\
\hline
\end{tabular}

The range of expected warfarin dosage based only on polymorphisms in genes CYP2C9 (CYP2C9*2, 430C > T, rs 1799853 and CYP2C9*3, 1075A $>$ C, rs 1057910) and VKORC1 $(\mathrm{VKORC} 1 * 2,-1639 \mathrm{G}>\mathrm{A}$, rs9923231) and their combination (23). To determine the warfarin dose, we have to take into account age, race, weight, height, sex and other medications.

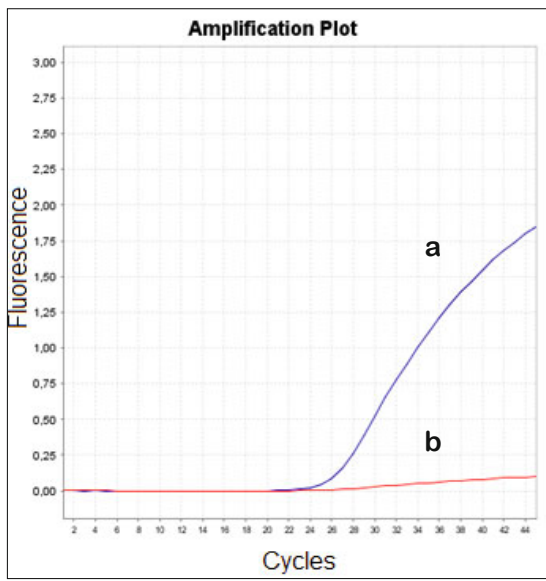

A - Wild type

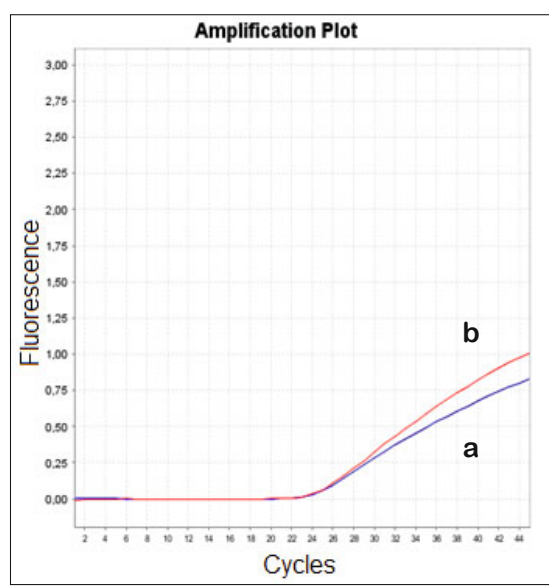

B - Heterozygous

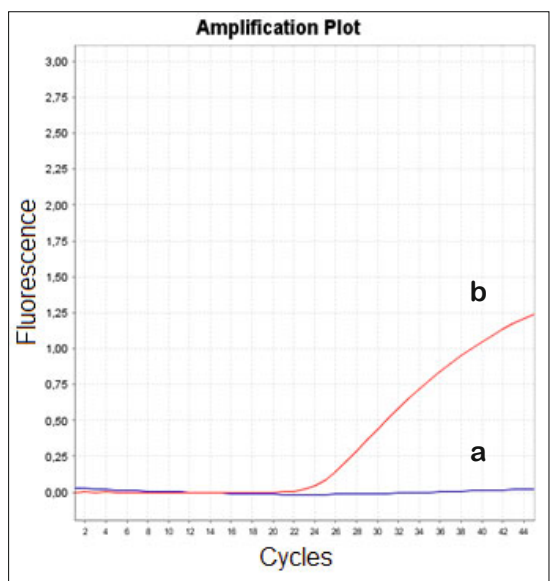

C - Mutant

Fig. 2. Schematic pictures of Allele-specific Real-Time PCR of polymorphisms in genes CYP2C9 (430C $>$ T, rs1799853 and 1075A $>C$, rs1057910) and VKORC1 (1173C $>$ T, rs9934438) (a - Wild-type allele, b - mutant allele).

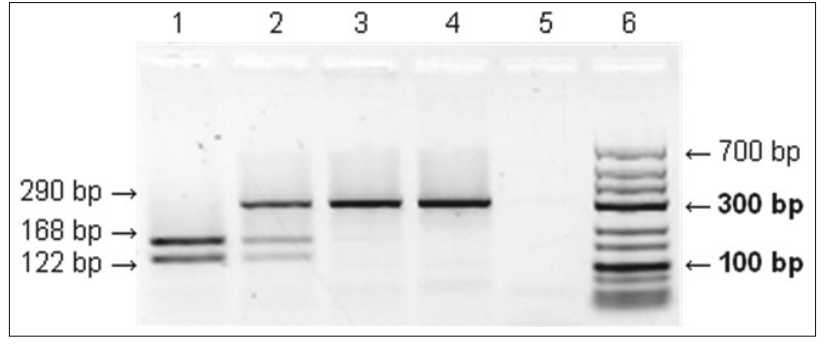

Fig. 3. PCR-RFLP of VKORC1 -1639G >A, rs9923231 by HpaII. 1 Wild-Type with GG genotyp $(168+122$ bp $), 2$ - Heterozygot with GA genotyp (290 + $168+122$ bp), 3 - Mutant with AA genotyp (290 bp), 4 - Undigested control (290 bp), 5 - Negative control, 6 - Molecule marker - O'GeneRuler Low Range DNA Ladder (700, 500, 400, 300, 200, 150, 100, 75, 50 and 25 bp).

nucleotide polymorphisms CYP2C9*2 (430C $>$ T), CYP2C9*3 $(1075 \mathrm{~A}>\mathrm{C}), \mathrm{VKORC} 1 * 2(1173 \mathrm{C}>\mathrm{T})$ were tested in a control group (112 randomly selected individuals) by allele-specific Real-Time PCR. The reaction was performed in $10-\mu 1$ volumes containing approximately $100 \mathrm{ng}$ of DNA. The assay for identification of CYP2C9 and VKORC1 alleles were obtained from Applied Biosystems: C_25625805_10 for CYP2C9*2 (430C $>$ T) rs 1799853 , C_27104892_10 for CYP2C9*3 (1075A >C) rs 1057910 and C_30204875_10 for VKORC1*2 (1173C $>$ T) rs9934438. The amplification of PCR consisted of an initial denaturation step at $95^{\circ} \mathrm{C}$ for $10 \mathrm{~min}$ followed by 45 amplification cycles $\left(95^{\circ} \mathrm{C}\right.$ for $15 \mathrm{sec}$ and $60^{\circ} \mathrm{C}$ for $60 \mathrm{sec}$ ). The frequencies of SNP VKORC $1 * 2$
$(-1639 \mathrm{G}>\mathrm{A})$ rs9923231was tested in a control group (112 randomly selected individuals) by using PCR-RFLP. The PCR reaction was performed in $20 \mu \mathrm{l}$ volumes containing approximately 100 ng of DNA, 2xPCR Master Mix (Fermantas), $0.5 \mu \mathrm{M}$ of each primer (Forward 5' GCCAGCAGGAGAGGGAAATA 3' and Rewerse 5'AGTTTGGACTACAGGTGCCT 3'). The amplification of PCR consisted of an initial denaturation step at $95{ }^{\circ} \mathrm{C}$ for $2 \mathrm{~min}$ followed by 35 amplification cycles $\left(95^{\circ} \mathrm{C}\right.$ for $15 \mathrm{sec}, 59$ ${ }^{\circ} \mathrm{C}$ for $30 \mathrm{sec}, 72{ }^{\circ} \mathrm{C}$ for $60 \mathrm{sec}$ ) and final polymerization step at $72{ }^{\circ} \mathrm{C}$ for $7 \mathrm{~min}$. After PCR reaction, all PCR products were digested by restriction enzyme HpaII (Fermentas) which cuts when $-1639 \mathrm{G}>\mathrm{A}$ polymorphisms is not present, and visualized by agarose gel electrophoresis.

To find out if the Slovak population is in to the Hardy-Weinberg equilibrium the results were evaluated by chi-square test. Allele's frequencies of different populations were determined and compared using Z-test.

\section{Results}

We determine the genotypes of CYP2C $9 * 2 \quad(430 \mathrm{C}>\mathrm{T})$ rs 1799853, CYP2C9*3 $(1075 \mathrm{~A}>\mathrm{C})$ rs1057910 and VKORC1*2 (1173C > T) rs9934438 by allele-specific Real-Time PCR (Fig 2) and VKORC1*2 (-1639G>A) rs9923231 by PCR-RFLP (Fig. 3). The frequency rate of selected polymorphisms in genes CYP2C9 and VKORC1 influencing the pharmacogenetics of warfarin was tested in the control group of 112 randomly selected individuals. 
Tab. 2. Haplotype frequency of CYP2C9 a VKORC1 in the control group of 112 randomly selected subjects.

\begin{tabular}{lcccccc}
\hline & $* 1 * 1$ & $* 1 * 2$ & $* 2 * 2$ & $* 1 * 3$ & $* 2 * 3$ & $* 3 * 3$ \\
\hline CYP2C9 & 77 & 16 & 2 & 14 & 3 & 0 \\
\hline VKORC1 & 41 & 58 & 13 & - & - & - \\
\hline
\end{tabular}

Tab. 3. Genotype frequency of CYP2C9 a VKORC1 in the control group of 112 randomly selected subjects.

\begin{tabular}{lcccc}
\hline $\begin{array}{l}\text { Gene and } \\
\text { substitution }\end{array}$ & CYP2C9 & CYP2C9 & VKORC1 & VKORC1 \\
\hline Wild-Type & CC -91 & AA -95 & GG -41 & CC -41 \\
& $(81.25 \%)$ & $(84.82 \%)$ & $(36.61 \%)$ & $(36.61 \%)$ \\
\hline Heterozygous & CT -19 & AC -17 & GA -58 & CT -58 \\
& $(16.96 \%)$ & $(15.18 \%)$ & $(51.79 \%)$ & $(51.79 \%)$ \\
\hline Mutant & TT -2 & CC -0 & AA -13 & TT -13 \\
& $(1.79 \%)$ & $(0.00 \%)$ & $(11.61 \%)$ & $(11.61 \%)$ \\
\hline
\end{tabular}

We defined the haplotypes (Tab. 2) and genotypes (Tab. 3) frequencies. To detect significant differences in the frequency of alleles between Slovak and other populations (Tabs 4 and 5) we used a statistical test method Z.

\section{Discussion}

The implementation of molecular-genetic diagnostic methods in pharmacology has brought forward the fact that the drugs with a narrow therapeutic index are now safer for setting up a proper dose in view of individual genome variations and individualized therapy. Warfarin belongs to this group of drugs, and their effect is influenced by polymorphisms in genes CYP2C9 and VKORC1. Detection of genotype before initiating the therapy could help avoid complications right at the beginning but also during longterm treatment.
Tab. 5. Percentage frequencies of polymorphisms VKORC $1 * 2$ in different population.

\begin{tabular}{|c|c|c|c|c|}
\hline Population & $\mathrm{n}$ & $\begin{array}{c}\% \\
\text { VKORC1*2 }\end{array}$ & $\frac{\mathrm{p}}{\mathrm{VKORC} 1 * 2}$ & References \\
\hline Slovak & 112 & 38 & & \\
\hline British & 297 & 47 & 0.10 & (22) \\
\hline Americans & 1119 & 37 & 0.84 & (43) \\
\hline Afro-Americans & 378 & 10 & 0.00 & (43) \\
\hline Italian & 147 & 40 & 0.74 & (7) \\
\hline$\overline{\text { Canadian }}$ & 126 & 39 & 0.87 & (44) \\
\hline Japanese & 828 & 91 & 0.00 & (32) \\
\hline French & 563 & 42 & 0.43 & (45) \\
\hline Swedish & 181 & 39 & 0.86 & (38) \\
\hline Chinese & 273 & 92 & 0.00 & (17) \\
\hline Turkish & 205 & 50 & 0.04 & (41) \\
\hline Holland & 1756 & 39 & 0.83 & (42) \\
\hline European-Americans & 216 & 50 & 0.44 & (46) \\
\hline Ethiopian & 154 & 20 & 0.00 & $(47)$ \\
\hline Lithuanian & 67 & 35 & 0.04 & $(48)$ \\
\hline Iranian & 126 & 55 & 0.43 & (49) \\
\hline Caucasians & 92 & 49 & 0.14 & $(17)$ \\
\hline Greek & 98 & 48 & 0.77 & (50) \\
\hline Romanian & 332 & 42 & 0.13 & $(51)$ \\
\hline
\end{tabular}

Frequencies of polymorphisms in gene VKORC1 (VKORC1*2) and comparison of our results with frequencies in other populations. Statistic evaluation of results at significance level of $\mathrm{p}<0.05$. Significant differences between Slovak and other populations are underlined.

It is estimated that seven million people are treated with warfarin worldwide. In Europe, it is approximately two million patients. However, more than $20 \%$ of them are hospitalized in the first six months because of bleeding complications caused by anticoagulant treatment (9). The pharmacogenetics of warfarin is significantly influenced by genetic factors such as the prevalence of polymorphisms in genes CYP2C9 and VKORC1.

Tab. 4. Percentage frequencies of polymorphisms CYP2C $9 * 2$ and CYP2C $9 * 3$ in different population.

\begin{tabular}{|c|c|c|c|c|c|c|}
\hline \multirow{2}{*}{ Population } & \multirow{2}{*}{$\mathrm{n}$} & \multicolumn{2}{|c|}{$\%$} & \multicolumn{2}{|c|}{$\mathrm{p}$} & \multirow{2}{*}{ References } \\
\hline & & CYP2C9*2 & CYP2C9*3 & CYP2C9*2 & CYP2C9*3 & \\
\hline$\overline{\text { Slovakia }}$ & 112 & 10 & 8 & & & \\
\hline British & 948 & 13 & 7 & 0.32 & 0.71 & (22) \\
\hline American & 935 & 11 & 6 & 0.74 & 0.46 & (27) \\
\hline Italian & 365 & 13 & 11 & 0.37 & 0.32 & $(7)$ \\
\hline Taiwanese & 37 & 0 & 3 & $\underline{0.00}$ & 0.19 & (28) \\
\hline Malaysian & 27 & 0 & 11 & $\underline{0.00}$ & 0.65 & (29) \\
\hline Israel & 384 & 13 & 8 & 0.37 & 1.00 & (30) \\
\hline Canadian & 189 & 11 & 8 & 0.78 & 1.00 & $(31)$ \\
\hline Japanese & 828 & 0 & 2 & $\underline{0.00}$ & $\underline{0.02}$ & (32) \\
\hline Russian & 62 & 9 & 5 & 0.83 & 0.43 & (33) \\
\hline Uruguayan & 53 & 13 & 11 & 0.58 & 0.55 & (34) \\
\hline French & 126 & 12 & 9 & 0.62 & 0.78 & (35) \\
\hline Croatian & 181 & 17 & 7 & 0.08 & 0.75 & (36) \\
\hline Singapore & 59 & 0 & 3 & $\underline{0.00}$ & 0.14 & (37) \\
\hline Swedish & 1487 & 11 & 7 & 0.73 & 0.71 & $(38)$ \\
\hline Chinese & 178 & 0 & 4 & $\underline{\underline{0.00}}$ & 0.18 & (39) \\
\hline Brazilian & 103 & 1 & 1 & $\underline{0.00}$ & $\underline{0.01}$ & $(40)$ \\
\hline Turkish & 205 & 13 & 10 & 0.42 & 0.55 & $(41)$ \\
\hline Holland & 1525 & 13 & 6 & 0.31 & 0.45 & (42) \\
\hline
\end{tabular}

Frequencies of polymorphisms in gene CYP2C9 (CYP2C9*2 and CYP2C9*3) and comparison of our results with frequencies in other populations. Statistic evaluation of results at significance level of $\mathrm{p}<0.05$. Significant differences between Slovak and other populations are underlined. 
We determined the SNPs genotype CYP2C $9 * 2$, CYP2C $9 * 3$ and $V K O R C 1 * 2$ of 112 individuals by using allele-specific RealTime PCR and PCR-RFLP. Frequencies of alleles with polymorphisms found in the current study are $10 \%$ (CYP2C9*2), $8 \%$ $(\mathrm{CYP} 2 \mathrm{C} 9 * 3)$ and $38 \%(\mathrm{VKORC} 1 * 2)$. Similar results were described by Takahashi et al 2006 (24), who determined the frequency of the same alleles was $14 \%, 11 \%$ and $42 \%$ in 115 subjects of Caucasian population. Polymorphisms in genes CYP2C9 and VKORC1 play an important role in the dosage of warfarin. Based on the results mentioned above, $25 \%$ of Slovak population was found to need a standard dose of warfarin ( $5 \mathrm{mg}$ per day). Taking into account a combination of the most severe polymorphisms CYP2C9*2, CYP2C9*3 and VKORC $1 * 2,44 \%, 23 \%$ and $8 \%$ of individuals need $4 \mathrm{mg}, 3 \mathrm{mg}$ and $2 \mathrm{mg}$ of warfarin per day, respectively based on the general therapeutic scheme implemented by Kitzmiller et al 2011 (23). Despite large advances in the prediction of stable warfarin dose, approximately $50 \%$ of the dose variability remains unexplained. Inter- and intraindividual variability is a big challenge in warfarin treatment. The anticoagulant effects of warfarin are modified also by diet and foods containing vitamin $\mathrm{K}$, although the dietary influences tend to be of more short-term character (25).

VKORC1*3 haplotype (3730G $>$ A, rs7294) was also defined and is present in $38 \%$ of Europeans (13). It causes an increase in the dosage of warfarin (AA) up to $30 \%$ compared with WT (7). The frequency of this allele in the Slovak population is $41 \%$ (26).

Slovak population is in Hardy-Weinberg equilibrium. The frequencies of selected SNPs correlate with other European populations $(7,22,33,35,36,38,42)$ and thus with Caucasians (17). This type of study was done for the first time in Slovakia.

Knowledge of the genotype of individuals allows physicians to adequately set up the warfarin dosage and avoid undesirable complications and life-threatening conditions, especially at the beginning of the warfarin therapy. The pharmacogenetic test is useful also for patients who are treated with warfarin in long term and suffer from serious side effects. FDA (Food and Drug Association) recommends genotype testing before the start of therapy.

\section{References}

1. Rettie AE, Tai G. The pharmocogenomics of warfarin: closing in on personalized medicine. Mol Interv 2006; 6: 223-227.

2. Hirsh J, Dalen JE, Anderson DR, Poller L, Bussey H, Ansell J, Deykin D. Oral anticoagulants: Mechanism of action, clinical effectiveness, and optimal therapeutic range. Chest 2001; 114: 445-469.

3. Hall M, Pirmohamed M. Pharmacogenetics. Informa Healthcare 2006; $324 \mathrm{pp}$.

4. Wadelius M, Pirmohamed M. Pharmacogenetics of warfarin: current status and future challenges. Pharmacogenomics J 2007; 7: 99-111.

5. Aithal G, Day CP, Kesteven PJ, Daly AK. Association of polymorphisms in cytochrome $\mathrm{P} 450 \mathrm{CYP} 2 \mathrm{C} 9$ with warfarin dose requirement and risk of bleeding complications. Lancet 1998; 353: 717-719.

6. Wu SM, Cheung WF, Frazier D, Stafford DW. Cloning and expression of the cDNA for human $\gamma$-glutamyl carboxylase. Science 1991; 254 : 1634-1636.
7. D'Andrea G, D'Ambrosio RL, Di Perna P, Chetta M, Santacroce R, Brancaccio V, Grandone E, Margaglione M. A polymorphism in the VKORC1 gene is associated with an interindividual variability in the dose-anticoagulant effect of warfarin. Blood 2005; 105: 645-649.

8. Lee CR, Goldstein JA, Pieper JA. Cytochrome P450 2C9 polymorphisms: a comprehensive review of the in-vitro and human data. Pharmacogenetics 2002; 12: 251-263.

9. Epstein RS, Moyer TP, Aubert ME, O'Kane DJ, Xia F, Vebrugge RR, Gage BF, Teagarden JR. Warfarin genotyping reduces hospitalization rates. Results from the MM-WES (Medco-Mayo warfarin effectiveness study). J. Am. College of Cardiology Foundation 2010; 55: 2804-2812.

10. van der Weide J, Steijns LS, van Weelden MJ, de Haan K. The effect of genetic polymorphism of cytochrome P450 CYP2C9 on phenytoin dose requirement. Pharmacogenetics 2001; 11: 287-91.

11. Kirchheiner J, Brockmoller J. Clinical consequences of cytochrome P450 2C9 polymorphisms. Clin Pharmacol Ther 2005; 77: 1-16.

12. Au N, Rettie AE. Pharmacogenomics of 4-Hydroxycoumarin Anticoagulants, Informa healthcare 2008; 40: 355-375.

13. Borgiani P, Ciccacci C, Forte V, Romano S, Federici G, Novelli G. Allelic variants in the $\mathrm{CYP} 2 \mathrm{C} 9$ and $\mathrm{VKORC} 1$ loci and interindividual variability in the anticoagulant dose effect of warfarin in Italians. Pharmacogenomics 2007; 8: 1545-1550.

14. Zanger UM, Turpeinen M, Klein K, Schwab M. Functional pharmacogenetics/genomics of human cytochromes P450 involved in drug biotransformation. Anal Bioanal Chem 2008; 392:1093-1108.

15. Rieder MJ, Reiner AP, Gage BF, Nickerson DA, Eby CHS, McLeod HL, Blough DK, Thummel KE, Veenstra DL, Rettie AE. Effect of VKORC1 haplotypes on transcriptional regulation and warfarin dose. $\mathrm{N}$ Engl J Med 2005; 352: 2285-2293.

16. Owen RP, Gong L, Sagreiya H, Klein TE, Altma RB. VKORC1 pharmacogenomics summary, Pharmacogenetics and Genomics 2010; 20: 642-644.

17. Yuan HY, Chen JJ, Lee MT, Wung JC, Chen YF, Charng MJ, Lu MJ, Hung CR, Wei CY, Chen CH, Wu JY, Chen YT. A novel functional VKORC1 promoter polymorphism is associated with inter-individual and inter-ethnic differences in warfarin sensitivity. Hum Mol Genet 2005; 14 : $1745-1751$.

18. Oldenburg J, Watzka M, Rost S, Müller CR. VKORC1: molecular target of coumarins. J Thromb Haemost 2007; 5: 1-6.

19. Matyškova M, Čech Z. Warfarin a farmakogenetika. Klin Biochem Metab 2009; 38: 215-219.

20. Yang L, Ge W, Yu F, Zhu H. Impact of VKORC1 gene polymorphism on interindividual and interethnic warfarin dosage requirement - A systematic review and meta analysis. Thrombosis Research 2010; 125: 159-166.

21. Hallak HO, Wedlund PJ, Modi MW, Patel IH, Lewis GL, Woodruff B, Trowbridge AA. High clearance of (S)-warfarin in a warfarin-resistant subject. Br J Clin Pharmacol 1993; 35: 327-330.

22. Sconce EA, Khan TI, Wynne HA, Avery P, Monkhouse L, King BP, Wood P, Kesteven P, Daly AK, Kamali F. The impact of CYP2C9 and VKORC1 genetic polymorphism and patient characteristics upon warfarin dose requirements: proposal for a new dosing regimen. Blood 2005; 106: 2329-2333.

23. Kitzmiller JP, Groen DK, Phelps MA, Sadee W. Pharmacogenomic Testing: Relevance in Medical Practice. Cleve Clin J Med 2011; 78: 243-257. 
24. Takahashi H, Wilkinson GR, Nutescu EA, Morita T, Ritchie MD, Scordo MG, Pengo V, Barban M, Padrini R, Ieiri I, Otsubo K, Kashima T, Kimura S, Kijima S, Echizen H. Different contributions of polymorphisms in VKORC1 and CYP2C9 to intra- and inter-population differences in maintenance dose of warfarin in Japanese, Caucasians and African-Americans. Pharmacogenet Genom 2006; 16: 101-110.

25. Levine MN, Raskob G, Landefeld S, Kearon C. Hemorrhagic complications of anticoagulant treatment. Chest 1998; 114: 511-523.

26. Déžiová L'. Molekulárno-genetická analýza polymorfizmov v génoch CYP2C9 a VKORC1 vplývajúcich na antikoagulačnú terapiu warfarínom. Diplomová práca 2011; 70 pp.

27. Carlquist JF, Horne BD, Muhlestein JB, Lappé DL, Whiting BM, Kolek MJ, Clarke JL, James BC, Anderson JL. Genotypes of the cytochrome $\mathrm{p} 450$ isoform, CYP2C9, and the vitamin K epoxide reductase complex subunit 1 conjointly determine stable warfarin dose: a prospective study. J Thromb Thrombolysis 2006; 22: 191-197.

28. Chern HD, Ueng TH, Fu YP, Cheng CW. CYP2C9 polymorphism and warfarin sensitivity in Taiwan Chinese. Clin Chim Acta 2006; 367: $108-113$.

29. Gan GG, Phipps ME, Ku CS, Teh A, Sangkar V. Genetic polymorphism of the CYP2C9 subfamily of 3 different races in warfarin maintenance dose. Clin Pharmacol Ther. 2004; 80: 295-296.

30. Loebstein R, Vecsler M, Kurnik D, Austerweil N, Gak E, Halkin H, Almog S. Common genetic variants of microsomal epoxide hydrolase affect warfarin dose requirements beyond the effect of cytochrome P450 2C9. Clin Pharmacol Ther. 2005; 77: 365-372.

31. Moridani M, Fu L, Selby R, Yun F, Sukovic T, Wong B, Cole DE. Frequency of CYP2C9 polymorphisms affecting warfarin metabolism in a large anticoagulant clinic cohort. Clin Biochem 2006; 39: 606-612.

32. Mushiroda T, Ohnishi Y, Saito S, Takahashi A, Kikuchi Y, Saito S, Shimomura H, Wanibuchi Y, Suzuki T, Kamatani N, Nakamura Y. Association of VKORC1 and CYP2C9 polymorphisms with warfarin dose requirements in Japanese patients. J Hum Genet. 2006; 51: 249-53.

33. Pchelina SN, Sirotkina OV, Taraskina AE, Vavilova TV, Shwarzman AL, Schwartz EI. The frequency of cytochrome P450 2C9 genetic variants in the Russian population and their associations with individual sensitivity to warfarin therapy. Thromb Res 2005; 115: 199-203.

34. Raggio V. Esperon P. Lorenzo M. Taub I. Cuesta A. Rodriguez A. Ortiz V. Kuster F. Lluberas R. Stoll M. Variantes de los genes CYP2C9 y apolipoproteína $\mathrm{E}$ en la respuesta individual a la warfarina. Rev.Urug. Cardiol 2006; 21: 104-116.

35. Siguret V, Gouin I, Golmard JL, Geoffroy S, Andreux JP, Pautas E. Cytochrome P450 2C9 polymorphisms (CYP2C9) and warfarin maintenance dose in elderly patients. Rev Med Interne 2004; 25: 271-274.

36. Topić E, Stefanović M, Samardzija M. Association between the CY$\mathrm{P} 2 \mathrm{C} 9$ polymorphism and the drug metabolism phenotype. Clin Chem Lab Med. 2004; 42: 72-78.

37. Zhao F, Loke C, Rankin SC, Guo JY, Lee HS, Wu TS, Tan T, Liu TC, Lu WL, Lim YT, Zhang Q, Goh BC, Lee SC. Novel CYP2C9 genetic variants in Asian subjects and their influence on maintenance warfarin dose. Clin Pharmacol Ther 2004; 76: 210-219.

38. Wadelius M, Chen LY, Eriksson N, Bumpstead S, Ghori J, Wadelius C, Bentley D, McGinnis R, Deloukas P. Association of warfarin dose with genes involved in its action and metabolism. Hum Genet 2007; 121: $23-34$.
39. Miao L, Yang J, Huang C, Shen Z. Contribution of age, body weight, and CYP2C9 and VKORC1 genotype to the anticoagulant response to warfarin: proposal for a new dosing regimen in Chinese patients. Eur $\mathrm{J}$ Clin Pharmacol 2007; 63: 1135-1141.

40. Lima MV, Ribeiro GS, Mesquita ET, Victer PR, Vianna-Jorge R. CYP2C9 genotypes and the quality of anticoagulation control with warfarin therapy among Brazilian patients. Eur J Clin Pharmacol 2008; 64: 9-15.

41. Oner Ozgon G, Langaee TY, Feng H, Buyru N, Ulutin T, Hatemi AC, Siva A, Saip S, Johnson JA. VKORC1 and CYP2C9 polymorphisms are associated with warfarin dose requirements in Turkish patients. Eur J Clin Pharmacol 2008; 64: 889-894.

42. Teichert M, van Schaik RH, Hofman A, Uitterlinden AG, de Smet PA, Stricker BH, Visser LE. Genotypes associated with reduced activity of VKORC1 and CYP2C9 and their modification of acenocoumarol anticoagulation during the initial treatment period. Clin Pharmacol Ther 2009; 85: 379-386.

43. Limdi NA, McGwin G, Goldstein JA, Beasley TM, Arnett DK, Adler BK, Baird MF, Acton RT. Influence of CYP2C9 and VKORC1 1173C/T genotype on the risk of hemorrhagic complications in African-American and European-American patients on warfarin. Clin Pharmacol Ther 2008; 83: 312-321.

44. Michaud V, Vanier MC, Brouillette D, Roy D, Verret L, Noel N, TailIon I, O'Hara G, Gossard D, Champagne M, Goodman K, Renaud Y, Brown A, Phillips M, Ajami AM, Turgeon J. Combination of phenotype assessments and CYP2C9-VKORC1 polymorphisms in the determination of warfarin dose requirements in heavily medicated patients. Clin Pharmacol Ther 2008; 83: 740-748.

45. Bodin L, Verstuyft C, Tregouet DA, Robert A, Dubert L, FunckBrentano C, Jaillon P, Beaune P, Laurent-Puig P, Becquemont L, Loriot MA. Cytochrome P450 2C9 (CYP2C9) and vitamin K epoxide reductase (VKORC1) genotypes as determinants of acenocoumarol sensitivity. Blood 2005; 106: 135-140.

46. Limdi NA, McGwin G, Goldstein JA, Beasley TM, Arnett DK, Adler BK, Baird MF, Acton RT. Influence of CYP2C9 and VKORC1 $1173 \mathrm{C} / \mathrm{T}$ Genotype on the Risk of Hemorrhagic Complications in AfricanAmerican and European-American Patients on Warfarin. Clin Pharmacol Ther 2008; 83: 312-321.

47. Aklillu E, Leong C, Loebstein R, Halkin H, Gak E. VKORC1 Asp36Tyr warfarin resistance marker is common in Ethiopian individuals., Blood 2008; 111: 3903-3904.

48. Tatarūnas $V$, Lesauskaitė $V$, Veikutienė A, Jakuška $P$, Benetis R. The Influence of CYP2C9 and VKORC1 gene polymorphisms on optimal warfarin doses after heart valve replacement. Medicina 2011; 47: 25-30.

49. Azarpira N, Namazi S, Hendijani F, Banan M, Darai M. Investigation of allele and genotype frequencies of CYP2C9, CYP2C19 and VKORC1 in Iran. Pharmacol Report 2010; 62: 740-746.

50. Markatos CN, Grouzi E, Politou M, Gialeraki A, Merkouri E, Panagou I, Spiliotopoulou I, Travlou A. VKORC1 and CYP2C9 allelic variants influence acenocoumarol dose requirements in Greek patients. Pharmacogenomics 2008; 11: 1631-1638.

51. Buzoianu AD, Trifa AP, Mureşanu DF, Crişan S. Analysis of CYP2C9*2, CYP2C9*3 and VKORC1 -1639 G>A polymorphisms in a population from South-Eastern Europ. J Cell Mol Med 2012; 16: 2919-2924.

Received February 6, 2014. Accepted February 28, 2014. 